Niniejsza publikacja jest dostęna na licencji Creative Commons. Uznanie autorstwa-Użycie niekomercyjne-Bez utworów zależnych 3.0 Polska. Pewne prawa zastrzeżone na rzecz autora. Zezwala się na wykorzystanie publikacji zgodnie z licencja - pod warunkiem zachowania niniejszej informacji licencyjnej oraz wskazania autora jako właściciela praw do tekstu. Treść licencji jest dostępna na stronie: http://creativecommons.org/licenses/by-nc-nd/3.0/pl/

Lingwistyka Stosowana 23: 3/2017, 79-90

\author{
Alicja SZTUK \\ Uniwersytet Warszawski
}

\title{
Problemy i wyzwania polityki terminologicznej na przykładzie baz danych terminologicznych
}

\begin{abstract}
:
Problems and Challenges of Terminology Policy on the Example of Terminology Databases

Terminology planning is an important part of terminology policy. Strategies which aim at developing or regulating emerging and existing terminologies must be very well planned and implemented thoroughly. One of the most important element of terminology planning are terminology databases. They are supposed to be a reliable source of terminology standards, in particular in translation process. However, it has to be pointed out that not only developing new terminology databases is crucial, but also maintaining and updating of those already existing. This paper provides some results of the research conducted on the EU's multilingual term base IATE - Interactive Terminology for Europe. The research was carried out to determine the reliability of the already mentioned term base.
\end{abstract}

\section{Wstęp}

W dzisiejszym świecie coraz częściej podejmowane są świadome i zaplanowane działania w ramach polityki terminologicznej. Do jej najważniejszych elementów zalicza się bazy danych terminologicznych, które powinny być wiarygodnym źródłem norm terminologicznych, a w konsekwencji stanowić wsparcie w procesach komunikacyjnych, w szczególności tych z udziałem tłumacza. Należy jednak mieć na uwadze, że istotne jest nie tylko tworzenie, ale i utrzymanie - aktualizacja istniejącej infrastruktury terminologicznej. W przeciwnym razie bazy danych stają się stopniowo niewiarygodne i bezużyteczne. W artykule przedstawione zostaną wyniki badań przeprowadzonych pod kątem sprawdzenia wiarygodności jednej z największych, europejskich baz danych terminologicznych - IATE (Interactive Terminology for Europe). Materiałem badawczym poddanym analizie jest wybrana, polska i niemiecka terminologia z zakresu ochrony danych osobowych.

\section{Polityka terminologiczna}

Znaczenie terminologii $\mathrm{w}$ osiąganiu postępu jest niezaprzeczalne. W literaturze przedmiotu dotyczącej tego zagadnienia podkreśla się ogromne tempo jej przyrostu, a zarazem niemożność dokładnego oszacowania tego tempa, jak i spowolnienia tego procesu (zob. F. Grucza 2002: 96). Rozwój terminologii w oświacie, nauce, kulturze 
stanowi klucz do rozwoju tzw. społeczeństwa wiedzy. W związku z tym środowiska specjalistyczne coraz częściej podejmują decyzję o implementowaniu tzw. polityki terminologicznej. Ponieważ jest to w Polsce wyrażenie stosunkowo nowe, nie ma zbyt wielu źródeł definiujących te działania. Na podstawie kilku definicji obcojęzycznych (głównie anglojęzycznych), do których udało mi się dotrzeć, stworzyłam własną definicję polityki terminologicznej, która brzmi następująco: polityka terminologiczna to zamierzone, systematyczne, kontrolowane i wieloetapowe działania pewnych, posiadających w tym zakresie kompetencję organów lub społeczności, zarówno na poziomie lokalnym, regionalnym, krajowym czy międzynarodowym, często we współpracy z organizacjami rządowymi, przeprowadzane na terminologii, czyli pewnym składniku języków specjalistycznych.

Działania te, chociaż dość złożone i wieloetapowe, skierowane są na osiągnięcie ściśle określonych celów, takich jak m.in.: instytucjonalizacja normalizacji, tworzenie i utrzymanie infrastruktury terminologicznej, opracowywanie norm terminologicznych, słowników oraz oferowanie usług terminologicznych, takich jak: konsultacje i usługi szkoleniowe, sporządzanie dokumentacji terminologicznej, usługi informacyjne itd. Wszystkie wymienione cele pośrednie zmierzać mają jednak do zapewnienia komunikacji mono- oraz bilingwalnej, także tej specjalistycznej, na najwyższym poziomie. Systematyczne planowanie terminologii ukierunkowane jest ponadto na wsparcie polityki w zakresie informacji, wiedzy lub innowacji oraz strategię edukacyjną. Tendencja prowadzenia usystematyzowanej polityki terminologicznej powinna odpowiadać wymogom przyspieszonej dzisiaj globalizacji.

O tym, jak ważne są skoordynowane i zaplanowane działania terminologiczne świadczą liczne inicjatywy środowisk specjalistycznych $\mathrm{w}$ tym zakresie. Jedną z nich było opracowanie dokumentu Wytyczne polityki terminologicznej, w którym przedstawione zostały praktyczne wskazówki metodologiczne dla decydentów i osób odpowiedzialnych za politykę w zakresie długodystansowego rozwoju danego kraju i społeczności językowej. Publikacja opracowana została w porozumieniu z UNESCO, pod auspicjami Polskiego Towarzystwa Tłumaczy Przysięgłych i Specjalistycznych - TEPIS oraz Międzynarodowej Organizacji Terminologii Specjalistycznej - ISTO.

Decyzja o wdrażaniu polityki terminologicznej jest bardzo ważna dla każdej społeczności. Eksplozja informacji oraz potrzeba porozumiewania się, w tym usystematyzowania terminologii oraz kontrolowanego jej tworzenia, wymusza na społeczeństwach podjęcie skoordynowanych działań prowadzonych w ramach polityki terminologicznej. Społeczności językowe, które albo nie panują nad przyrostem nowych terminów, albo nie wykształciły terminologii naukowej i technicznej, są z jednej strony narażone na szeroko rozumiane problemy komunikacyjne lub w drugim przypadku są zmuszone do wykorzystania innego, bardziej rozwiniętego języka dla potrzeb komunikacji dziedzinowej. Ponieważ obecnie komunikacja jest w dużym stopniu wspierana przez technologie informacyjne, brak terminologii prowadzi także, w sposób pośredni, lecz nieunikniony, do wykluczenia cyfrowego.

W związku z powyższym planowanie terminologii stało się żywotną kwestią w różnych krajach, począwszy od tych słabo rozwiniętych, przez te rozwijające się, aż 
po wysoko rozwinięte. Efekty dobrze prowadzonej polityki terminologicznej są łatwo zauważalne, co widać na przykładzie krajów takich jak, m.in. Francja czy Kanada, które stawiane są w literaturze przedmiotu za wzór w tym zakresie (zob. A. Moszko, 2010: 113). Kraje te odnoszą sukcesy na tej płaszczyźnie, ponieważ przywiązują dużą wagę do skoordynowanych działań językowo-terminologicznych, na poziomie zarówno regionalnym, jak i krajowym, a także na arenie międzynarodowej. Ponadto ich organizacje normalizacyjne działają w porozumieniu $\mathrm{z}$ rządami krajowymi. Oprócz powoływania licznych instytucji normalizacyjnych, kraje te cieszą się uznaniem za sprawą swoich baz danych terminologicznych, tzw. TDBs (Terminology Databases). Bazy te są więc nieocenionym wsparciem w przypadku komunikacji, zarówno mono- jak i bilingwalnej, w szczególności tej z udziałem osoby trzeciej - tłumacza. Dzieje się tak nie tylko dlatego, że ich bazy danych terminologicznych są opracowywane z najwyższą starannością, ale przede wszystkim dlatego, że są one regularnie aktualizowane, w celu zarówno tworzenia, jak i utrzymania krajowej infrastruktury terminologicznej na odpowiednio wysokim poziomie. Nasuwa się więc wniosek, że jednym z relewantnych elementów polityki terminologicznej musi być, obok opracowywania baz danych, ich regularna aktualizacja. Aktualizacje baz danych terminologicznych powinny zawsze przebiegać dwutorowo: $\mathrm{z}$ jednej strony bazy muszą być uzupełniane o nowe terminy, a z drugiej strony muszą być weryfikowane pod kątem trafności terminów wprowadzonych do baz we wcześniejszych etapach. Jeśli wskazany warunek nie jest spełniany, bazy danych terminologicznych stają się stopniowo niewiarygodne, a w końcu nawet bezużyteczne. Tak więc kluczowym pytaniem w kontekście użyteczności baz danych terminologicznych powinno być pytanie nie o same bazy jako takie czy ich tworzenie (bo to jest kwestia oczywista), lecz o ich regularną weryfikację i aktualizację.

\subsection{Cele polityki terminologicznej}

Podstawowym celem prowadzenia działań w ramach polityki terminologicznej jest uzyskanie jednolitej i adekwatnej terminologii. Nieadekwatna terminologia jest bowiem jednym z kluczowych czynników nierównej dostępności językowej, której wynikiem może być tzw. ,analfabetyzm funkcjonalny” w kontekście dostępu do wiedzy i informacji. Działania terminologiczne mają być więc ukierunkowane przede wszystkim na zminimalizowanie ryzyka związanego z szeroko pojętym wykluczeniem, zarówno w zakresie językowym, jak i w zakresie dostępu do wiedzy. Ponadto uporządkowana, znormalizowana terminologia ułatwia nam dostęp do wiedzy, kultury i technologii. Niemożność komunikowania, a w szczególności w kwestiach specjalistycznych, skutkować może brakiem dostępu do najnowszych osiągnieć nauki, kultury i technologii. Warty przypomnienia jest również fakt, że jednolita terminologia jest niemalże gwarantem płynnej myśli naukowej i technologicznej.

Inne cele planowania terminologii to m.in.: poprawienie jakości komunikacji, $\mathrm{w}$ tym tłumaczeń, zmniejszenie nakładów finansowych na ich wykonywanie, bardziej efektywna komunikacja, tak mono-, jak i bilingwalna $\mathrm{z}$ udziałem tłumacza. Ponadto ustabilizowana sytuacja terminologiczna w wielu branżach przekłada się na cele czysto pragmatyczne, takie jak m.in. rozwój innowacyjności, wzrost produktywno- 
ści i konkurencyjności danego np. kraju oraz poprawę edukacji. Poza tym działalność terminologiczna ma także na celu uzyskanie rozmaitych produktów oraz usług terminologicznych. Do tych pierwszych zaliczyć można: normy terminologiczne, słowniki języków specjalistycznych, glosariusze, bazy danych terminologicznych. Za usługi terminologiczne uznaje się m.in. konsultacje terminologiczne, usługi szkoleniowe, informacje i dokumentację terminologiczną, prace terminologiczne zlecane zewnętrznym wykonawcom, doradztwo w zakresie doboru i stosowania narzędzi terminologicznych itd. I w końcu efektywnie prowadzona polityka terminologiczna to łatwiejsza i bezpieczniejsza wymiana danych terminologicznych między podmiotami - tak aby zminimalizować ryzyko utraty danych, jak i pozyskanie tych danych przez osoby niepowołane.

\subsection{Podstawowe obszary polityki terminologicznej}

Za najważniejsze obszary polityki terminologicznej uznaje się tworzenie, aktualizację i upowszechnianie baz danych terminologicznych, jak również rodzaj zapisu danych gwarantujący ich kompatybilność z innymi bazami oraz możliwie znikomą utratę danych w przypadku ich przesyłania lub konwertowania. Po drugie w polu zainteresowań polityki terminologicznej znajduje się normalizacja i instytucjonalizacja, zarówno krajowa, jak i międzynarodowa, a także ścisła współpraca między tymi organami. Nowością w spektrum zainteresowań polityki terminologicznej są nowoczesne rozwiązania, tzw. terminotyki. Terminotyka, to wyrażenie jeszcze niezakorzenione $\mathrm{w}$ języku polskim i niewystępujące $\mathrm{w}$ żadnym słowniku ${ }^{1}$. $\mathrm{Z}$ czysto językowego punktu widzenia jest to hybryda językowa powstała $\mathrm{z}$ wyrażeń terminologia oraz informatyka. Ta nowa, ale bardzo obiecująca dziedzina, to możliwości wykorzystania osiągnięć informatyki do badań nad terminologią. Wspomnieć należy, że dziedzina ta wydaje się być jedynym rozwiązaniem dla coraz większych zasobów terminologicznych, których człowiek, ani nawet grupa ludzi, nie jest w stanie zoperacjonalizować. Ostatnim punktem ciężkości efektywnej polityki terminologicznej jest budowanie kompetencji ludzkich. Należy umożliwiać wysoko wykwalifikowanym specjalistom dalszy rozwój i doszkalanie swoich umiejętności, tak aby mogli oni „zajmować się” terminologią na najwyższym poziomie profesjonalizmu.

\section{Etapy działań w ramach polityki terminologicznej}

Etapy najważniejszych działań w ramach polityki terminologicznej przedstawię za autorami wspomnianego już dokumentu zatytułowanego Wytyczne polityki terminologicznej. Dokument w polskiej wersji językowej został opublikowany w roku 2007 i zakłada on cztery główne etapy działań w ramach polityki terminologicznej:

ETAP I - Przygotowanie do podjęcia polityki terminologicznej. Etap ten obejmuje m.in.:

- ocenę środowiska językowego;

- wstępne oszacowanie kosztów przedsięwzięcia;

\footnotetext{
${ }^{1}$ Stan na 23.04.2017 r.
} 
- zwiększenie świadomości językowej wśród użytkowników danej społeczności językowej;

- rozeznanie w aktualnych regulacjach prawnych w tym zakresie;

- przygotowanie wstępnej dokumentacji;

- organizację procesu konsultacyjnego.

Etap II - Kształtowanie polityki terminologicznej. Etap ten obejmuje:

- opracowanie propozycji konkretnych działań;

- opracowanie planu koordynacji np. z działaniami politycznymi w tym zakresie;

- przygotowanie ostatecznego projektu realizacji przedsięwzięcia (z uwzględnieniem już istniejącej infrastruktury terminologicznej).

Etap III - Realizowanie polityki terminologicznej. Etap ten obejmuje:

- zarządzanie realizacją, m.in. ostateczne decyzje, które organizacje odpowiadają za realizację poszczególnych etapów;

- operacyjne oraz organizacyjne planowanie realizacji, np. sposób koordynacji projektu;

- planowanie działań upowszechniających i promocyjnych.

Etap IV - Utrzymanie infrastruktury terminologicznej. Etap ten obejmuje:

- mechanizmy dostosowywania infrastruktury terminologicznej do potrzeb zmieniającego się świata;

- aktualizację i unowocześnianie rozwiązań opracowanych we wcześniejszych etapach.

\section{Przekrój działań normalizacyjno-terminologicznych w Polsce i na świecie}

Nie sposób w jednym artykule przedstawić wszystkich organizacji zajmujących się kwestiami normalizacji terminologicznej. W związku z powyższym przedstawione zostaną jedynie te, które mają istotny wpływ na stan polityki terminologicznej w Polsce i na świecie (mam na myśli organizacje o zasięgu krajowym i międzynarodowym).

Najważniejszą, międzynarodową organizacją o charakterze normalizacyjnym jest Międzynarodowa Organizacja Normalizacyjna (ISO - International Organization for Standardization). ISO jest organizacją pozarządową i zrzesza krajowe organizacje normalizacyjne. Warty uwagi jest również fakt, że ISO jest oficjalną nazwą, a nie skrótowcem. Jeśli chodzi o strukturę ISO, jest ona wzorowana na strukturze m.in. DIN, czyli Niemieckiego Instytutu Normalizacyjnego (Deutsches Institut für Normung), a oznacza to, że składa się na nią kilkaset komitetów technicznych i grup roboczych zajmujących się dyskusjami technicznymi oraz Komitet Główny, w którym po jednym głosie mają wszystkie kraje członkowskie. Głównym zadaniem ISO jest opracowywanie dokumentów normalizacyjnych, tzw. norm oraz aktualizowanie już istniejących dokumentów normalizacyjnych. Projekty zmian lub projekty nowych norm zwane draftami może składać każda organizacja członkowska. Następnie projekty są dyskutowane w grupach roboczych, w których po uzyskaniu ogólnego konsensusu draft zamienia się w project, który może uzyskać status oficjalnej normy, po tym jak 3/4 członków Komitetu Głównego zaopiniuje go pozytywnie. 
Skupiając się stricte na zadaniach normalizacyjno-terminologicznych $\mathrm{w}$ ramach ISO, wspomnieć należy o Komitecie Technicznym ISO/TC 37 Terminology and other language and content resources. Jest to komitet, którego działania skupiają się na normalizacji: „zasad, metod i zastosowań dotyczących terminologii oraz innych zasobów językowych w kontekście komunikacji wielojęzycznej i różnorodności kulturowej"'.

$\mathrm{Na}$ arenie europejskiej za opracowywanie, przyjmowanie i rozpowszechnianie norm europejskich oraz innych dokumentów normalizacyjnych we wszystkich obszarach gospodarki oprócz elektrotechniki, elektroniki i telekomunikacji, odpowiedzialny jest Europejski Komitet Normalizacyjny (CEN - Comité européen de normalisation), który również angażuje się w działalność normalizacyjnoterminologiczną.

Na szczeblu krajowym, w Polsce, działalność normalizacyjną prowadzi Polski Komitet Normalizacyjny (PKN). Prowadzi on czynną współpracę, zarówno z CEN, jak i ISO, a właściwie z jego komitetami technicznymi i grupami roboczymi. W ramach PKN powołany został w roku 1994 komitet techniczny KT nr 256 ds. Terminologii, Innych Zasobów Językowych i Zarządzania Treścią. Poniżej przedstawię skrócony opis jego działalności, który opublikowany został na stronie internetowej $\mathrm{PKN}^{3}$ :

Ogólne zasady i metody działalności terminologicznej oraz normy w zakresie terminologii, zasobów językowych, zarządzania treścią, tłumaczeń pisemnych i ustnych oraz związanej z tym technologii, w tym zasady i metody tworzenia systemów pojęć, terminów, zasady i metody wprowadzania międzynarodowych i regionalnych norm terminologicznych oraz wymiany danych językowych pomiędzy różnymi systemami. Opracowywanie i sposób prezentacji Norm i innych dokumentów terminologicznych, w tym układ, zawartość i sposób prezentacji haseł terminologicznych, symbole leksykograficzne i konwencje typograficzne, kody nazw języków i szeregowanie alfabetyczne alfanumerycznych danych terminologicznych. Komputerowe wspomaganie działalności terminologicznej i zarządzania zasobami językowymi, w tym elementy danych terminologicznych, format rekordów (zapisów) do wymiany danych terminologicznych, zasady tworzenia terminologicznych baz danych i innych zasobów językowych oraz zarządzania nimi, zastosowanie języka SGML (Standardized General Mark-Up Language) oraz tworzenie zasobów językowych i ich klasyfikacji w oparciu o metodologię NLP (przetwarzanie języka naturalnego).

Ponadto na uwagę, ze względu na swój wkład w prace normalizacyjnoterminologiczne, zasługują także, m.in.: TERMISTI (The Termist Research Center). Jest to Centrum Badan nad Lingwistyką Stosowaną przy Instytucie Tłumaczy Języka Mówionego i Pisanego Szkoły Wyższej w Brukseli, które posiada jedno z wiodących laboratoriów terminologicznych na świecie, zorientowanych na wielojęzyczne bazy danych terminologicznych. Ponadto chciałabym wskazać na działania Europejskiego Stowarzyszenia Terminologicznego (The European Association for Terminology), czy Komisji Terminologicznej przy Międzynarodowym Komitecie Slawistów.

${ }^{2}$ https://en.wikipedia.org/wiki/ISO/TC_37, thum.: A. Sz.

${ }^{3}$ http://pzn.pkn.pl/kt/?pid=kikt\&id=9000128698. 
Swój wkład w działalność terminologiczną ma w Polsce także Rada Języka Polskiego, w ramach której funkcjonują komitety zadaniowe, np. Zespół Terminologii Informatycznej.

\section{Bazy danych terminologicznych}

Bazy danych terminologicznych (TDBs - Terminology Databases) uznawane są za jedno z najważniejszych narzędzi polityki terminologicznej. Narzędzie to dzięki możliwościom, jakie dały nam zasoby informatyczne, stało się funkcjonalne ze względu na możliwość utrwalania, przechowywania, przetwarzania i udostępniania danych terminologicznych, zgodnie z zasadami profesjonalizmu. Bazy danych terminologicznych cieszą się coraz większą popularnością, gdyż dzięki osiągnięciom informatycznym są w stanie zoperacjonalizować coraz większe ilości danych terminologicznych, a więc możliwe jest tworzenie wielojęzycznych i wielodziedzinowych baz danych, które dodatkowo tworzyć mogą całe siatki baz danych z centrum dowodzenia - tzw. bazą matką (Mother Base) na czele. Jest to bardzo istotna kwestia $\mathrm{z}$ punktu widzenia specyfiki samej terminologii, gdyż, jak pisze M. OlpińskaSzkiełko: ,pojęcia (czyli jedna z części składowych terminów - A. Sz.) nie występują niezależnie od siebie, lecz są ze sobą powiązane wzajemnymi relacjami” (M. Olpińska-Szkiełko 2016: 86, tłum.: A. Sz.). I te relacje mogą być właśnie uwzględnione w bazach danych tak, aby każdy użytkownik wiedział, do której siatki terminologicznej przynależy dany termin i w jakich jest on relacjach $\mathrm{w}$ stosunku do innych terminów z tej rodziny. Ponadto współczesne bazy danych są coraz częściej tworzone tak, aby były kompatybilne $\mathrm{z}$ innymi bazami, w celu umożliwienia użytkownikowi korzystania z coraz większych zasobów terminologicznych. Takie wielojęzyczne bazy danych służyć mają efektywnej wymianie informacji między specjalistami różnych narodowości i powinny być wiarygodnym źródłem wiedzy na temat norm terminologicznych dla tłumaczy tekstów specjalistycznych. Do największych, międzynarodowych baz danych terminologicznych należą: IATE, LOGOS, ILOTERM, EURLex, UNTERM czy UNESCOTERM.

\section{IATE (Interactive Terminology for Europe) - badanie wiarygodności bazy}

IATE, czyli Interactive Terminology for Europe, to projekt tzw. Interaktywnej Terminologii dla Europy. Jest to wielojęzyczna, elektroniczna baza terminologii stosowanej przez różne instytucje Unii Europejskiej. Projekt bazy zainicjowano w 1999 r., by umożliwić łatwiejszy dostęp do unijnej terminologii. Od 2004 r. z bazy zaczęły korzystać instytucje i agencje Unii Europejskiej, a 28 czerwca 2007 r. baza została oficjalnie udostępniona na stronie internetowej, by umożliwić sporządzanie jednolitej pod względem terminologicznym dokumentacji unijnej oraz jej tłumaczenie na pozostałe języku unijne. Baza zawiera ponad 1,5 miliona wielojęzycznych haseł. Do IATE włączono istniejące wcześniej bazy terminologii opracowane przez służby językowe poszczególnych instytucji unijnych, m.in.: Parlamentu Europejskiego, Komisji Europejskiej czy Trybunału Obrachunkowego. Osoby odpowiedzialne za IATE deklarują, że do bazy codziennie dodawane są nowe terminy, a dotychczaso- 
we zasoby aktualizowane są na bieżąco. Ponadto na stronie internetowej bazy znaleźć można informację, że jej ogólnie dostępna część jest jedynie zweryfikowanym podzbiorem większych zasobów terminologicznych wykorzystywanych w codziennej pracy przez pracowników Unii Europejskiej.

Aby zweryfikować wiarygodność bazy IATE przeprowadziłam badanie na próbce polskich i niemieckich terminów z zakresu ochrony danych osobowych. Pierwsza część terminologii wyekscerpowana została z polskiej i niemieckiej ustawy o ochronie danych osobowych ${ }^{4}$ oraz z Dyrektywy europejskiej dotyczącej ochrony danych ${ }^{5}$, druga część $\mathrm{z}$ aktualnych tekstów branżowych pozyskanych głównie ze stron internetowych, np. czasopism o tematyce informatycznej ${ }^{6}$. Pierwsza część badania przeprowadzona została na łącznie 20 polskich i niemieckich terminach, druga część na łącznie 40 terminach w języku polskim lub niemieckim. Poniżej przedstawione zostały dwa tabelaryczne zestawienia części wyników badania. Zaprezentowane części są jednak reprezentatywne i wskazują jednoznacznie na tendencje zaobserwowane w przypadku pozostałych wybranych do badania terminów.

\begin{tabular}{|l|ll|}
\hline Terminy z tekstów normatywnych & & \multicolumn{1}{|c|}{ IATE } \\
\hline Verarbeitung personenbezogener Daten & - & Verarbeitung personenbezogener Daten \\
(Verarbeitung) & - & Umgehen mit Daten \\
& - & Behandeln der Daten \\
\hline przetwarzający & - & podmiot przetwarzający \\
& - & przetwarzający \\
\hline Auftragsverarbeiter & - & Datenprozessor \\
& - & Auftragsverarbeiter \\
\hline Dritter & - & Dritter \\
& - & Drittland \\
& - & drittes Land \\
& - & Drittstaat \\
& - & Nicht-EU-Staat \\
\hline dane sensytywne & - & dane szczególnie chronione \\
& - & dane wrażliwe \\
& - & dane sensytywne \\
\hline personenbezogene Daten & - & dane delikatne \\
\hline
\end{tabular}

${ }^{4}$ Bundesdatenschutzgesetz vom 20. Dezember 1990 mit späteren Änderungen; Ustawa z dnia 29 sierpnia 1997 r. o ochronie danych osobowych.

${ }^{5}$ Richtlinie 95/46/EG des Europäischen Parlaments und des Rates vom 24. Oktober 1995 zum Schutz natürlicher Personen bei der Verarbeitung personenbezogener Daten und zum freien Datenverkehr; Dyrektywa 95/46/WE Parlamentu Europejskiego i Rady z dnia 24 października 1995 r. w sprawie ochrony osób fizycznych w zakresie przetwarzania danych osobowych i swobodnego przepływu tych danych.

6 Strony te, to m.in.: www.niebezpiecznik.pl, www.zaufanatrzeciastrona.pl, www.panoptykon.org, www.secure-one.de, www.datenschutz.de itd. 


\begin{tabular}{|l|ll|}
\hline & - & persönliche Daten \\
& - & Personaldaten \\
& - & Individualinformationen \\
- & personenbezogene Informationen \\
& - & private Daten \\
\hline & - & Individualdaten \\
\hline
\end{tabular}

Tabela 1. Terminy z tekstów normatywnych vs. baza IATE.

\begin{tabular}{|l|l|}
\hline \multicolumn{1}{|c|}{ Terminy z tekstów branżowych } & \\
\hline PL buforowanie & $\mathrm{PL}-$ \\
DE Puffering & $\mathrm{DE}-$ \\
\hline PL skimming & $\mathrm{PL}-$ \\
DE Skimming, Datenausspähen & $\mathrm{DE}-$ \\
\hline $\begin{array}{l}\text { PL O-day-exploit (Zero-day exploit) } \\
\text { DE Zero Day Exploit }\end{array}$ & $\mathrm{PL}-$ \\
\hline $\begin{array}{l}\text { PL netiquette, internet ethics, nethics, cy- } \\
\text { bermanners }\end{array}$ & $\mathrm{DE}-$ \\
$\begin{array}{l}\text { DE Netiquette, Netikette, Netzverhaltungs- } \\
\text { regeln }\end{array}$ & DE Internet-Verhaltenskodex \\
\hline $\begin{array}{l}\text { PL atak hybrydowy, blended threat } \\
\begin{array}{l}\text { DE Blended threat, gemischte Bedrohung, } \\
\text { hybrider Angriff }\end{array}\end{array}$ & DE - \\
\hline $\begin{array}{l}\text { PL tylne wejście/ drzwi, backdoor, luka w } \\
\text { zabezpieczeniach systemu } \\
\text { DE Backdoor, Trapdoor, Hintertür }\end{array}$ & PL backdoor \\
\hline
\end{tabular}

Tabela 2. Terminy z tekstów branżowych vs. baza IATE.

\section{Wnioski}

Z przeprowadzonego badania wiarygodności bazy danych terminologicznych IATE wynika, iż terminologia wprowadzona do bazy nie jest jednolita i konsekwentnie używana. Wskazuje na to bogata, niedopuszczalna w przypadku terminów, synonimia (zob. tabela 1). Fakt współwystępowania wielu synonimów, a tym bardziej dla terminów używanych przez specjalistów z zakresu ochrony danych na co dzień, jak $\mathrm{np}$. dane wrażliwe, dziwi tym bardziej, że nie są to terminy nowe, lecz zakorzenione 
we wszystkich językach Unii Europejskiej. W związku z tym można wnioskować, iż autorzy bazy zignorowali zasadę 1:1, tzn. jeden termin odpowiada jednemu pojęciu. Ponadto zaobserwować można, że wbrew opinii autorów, baza nie jest aktualizowana lub nie jest aktualizowana w sposób efektywny. Świadczą o tym liczne braki w bazie terminów wprawdzie stosunkowo nowych, jednak będących w obiegu specjalistycznym, tj. używanych przez specjalistów w tekstach specjalistycznych (zob. tabela 2).

Mimo iż badanie zostało przeprowadzone na stosunkowo niewielkim materiale badawczym (20 terminów + 40 terminów), co stanowi tylko znikomą część całej prezentowanej $\mathrm{w}$ IATE terminologii oraz mimo że terminologia ta związana była tylko z jedną dziedziną specjalistyczną, można wysnuć hipotezę, że podobne tendencje dotyczyć mogą także innych dziedzin i innej terminologii prezentowanej przez IATE.

W związku z przytoczonymi argumentami uważam, iż baza danych terminologicznych IATE nie może być wiarygodnym źródłem wiedzy na temat użycia terminów oraz nie powinna być podstawą do tworzenia tłumaczeń z zakresu prawa europejskiego, a z pełnym przekonaniem tłumaczeń z zakresu ochrony danych osobowych. Prezentowane terminy mogą wprowadzać bowiem chaos thumaczeniowy i prowadzić do zakłóceń komunikacyjnych.

Przytoczona argumentacja oraz zaprezentowane wnioski skłaniają ponadto do dalszych, pogłębionych refleksji, które dotyczą sposobu aktualizowania bazy IATE, a także innych ogromnych baz terminologicznych. Nie da się zaprzeczyć, że utrzymanie istniejącej infrastruktury terminologicznej jest rzeczą niezmiernie istotną. W związku z tym oraz z dużymi zasobami bazy IATE, których efektywne zoperacjonalizowanie staje się dla ludzi powoli nieosiągalne, może jej twórcy powinni rozważyć nowoczesne rozwiązania, jakie daje nam informatyka, a w szczególności uczenie maszynowe (machine learning), a dokładniej rzecz ujmując zastosowanie tzw. samouczących się algorytmów. Inteligentne algorytmy usprawniają dziś tak wiele aspektów naszego życia, począwszy od portali randkowych, które szukają za nas naszej drugiej połowy, przez osobistą asystentkę typu $\mathrm{Siri}^{7}$, po inteligentne sklepy internetowe, które podpowiedzą, co może nam się spodobać. Dlaczego więc nie miałyby one być także kamieniem milowym w opracowywaniu, aktualizowaniu i utrzymywaniu baz danych terminologicznych?

\section{Bibliografia}

Grucza, F. (2002), Języki specjalistyczne - indykatory i/ lub determinanty rozwoju cywilizacyjnego, (w:) J. Lewandowski (red.), Języki specjalistyczne: Problemy technolinogwistyki, (Języki Specjalistyczne t. 1). Warszawa, 9-26.

\footnotetext{
${ }^{7}$ Siri - inteligentny osobisty asystent i nawigator wiedzy, który działa na systemie operacyjnym Apple iOS i MacOS Sierra. Aplikacja odpowiada na pytania i zalecenia oraz wykonuje działania poprzez przekazanie żądania do mikrofonu. Siri została wprowadzona jako aplikacja iOS dostępna w App Store przez Siri Inc., która została przejęta przez przedsiębiorstwo Apple 28 kwietnia 2010 roku.
} 
Moszko, A. (2010), Planowanie terminologiczne $w$ dobie globalizacji, (w:) B. Czopek-Kopciuch/ P. Żmigrodzki (red.), Język polski - wczoraj, dziś i jutro... Kraków, 108-118.

Olpińska-Szkiełko, M. (2016), Anthropozentrische Sprachtheorie und Fachsprachenforschung, (w:) „Lingwistyka Stosowana/ Applied Linguistics/ Angewandte Linguistik“ 18, 81-90. (http://www.ls.uw.edu.pl/documents/7276721/13590953/ 7+Magdalena+Olpi\%C5\%84ska-Szkie\%C5\%82ko+-

+ Anthropozentrische+Sprachtheorie+und+Fachsprachenforschung.pdf). [Pobrano 25.04.2017].

\section{Źródla internetowe}

http://iate.europa.eu/SearchByQueryLoad.do;jsessionid=GLW1YWW61KVHd5IKj8

VJtLt9UbxvGemlYKLKacCE2zGC1OYpOo3h!559570392?method=load [Pobrano 24.04.2017].

http://www.infoterm.info/pdf/activities/guidelines/Wytycznepolitykiterminologiczne

j_pl.pdf. [Pobrano 20.04.2017].

http://www.pkn.pl/sites/default/files/plan_dzialania_kt_256.pdf. [Pobrano

19.04.2017].

http://www.giodo.gov.pl/. [Pobrano 12.04.2017].

http://www.e-ochronadanych.pl/a, 179,zasady-i-priorytety-ochrony-danych-

osobowych-w-niemczech.html. [Pobrano 22.04.2017].

https://www.datenschutz.de. [Pobrano 12.04.2017].

http://www.wiwo.de/technologie/digitale-welt/datenschutz-obama-plant-aktionen-

gegen-cyberangriffe/7813176-2.html. [Pobrano 25.04.2017].

http://www.computerwoche.de/a/die-groessten-cyberangriffe-auf-

unternehmen,3214326. [Pobrano 21.04.2017]. http://eur-lex.europa.eu/legal-

content/PL/TXT/PDF/?uri=CELEX:32016R0679\&from=PL.[Pobrano 26.04.2017].

http://www.niebezpiecznik.pl. [Pobrano 12.04.2017].

http://www.zaufanatrzeciastrona.pl. [Pobrano 20.04.2017].

http://www.panoptykon.org. [Pobrano 20.04.2017].

http://www.secure-one.de. [Pobrano 14.04.2017].

http://www.spiegel.de/netzwelt/gadgets/nach-stagefright-weitere-android-

sicherheitsluecke-entdeckt-a-1046037.html. [Pobrano 24.04.2017].

http://www.forbes.pl/cyberprzestepcy-szukaja-nowych-punktow-ataku-na-

firmy,artykuly,203135,1,1.html. [Pobrano 12.04.2017].

http://www.forbes.pl/apple-kontra-fbi-czyli-szerszy-problem-szyfrowania-

danych,artykuly,203747,1,1.html. [Pobrano 20.04.2017].

http://www.forbes.pl/ataki-hakerskie-wzrost-zagrozen-

cyberatakami,artykuly,204222,1,1.html. [Pobrano 20.04.2017].

http://www.forbes.pl/christian-fredrikson-prezes-f-secure-

wywiad,artykuly,204487,1,1.html. [Pobrano 20.04.2017].

https://www.tagesschau.de/inland/cyberkampf-101.html. [Pobrano 23.04.2017].

https://www.fireeye.de/current-threats/how-cyber-attackers-get-in.html. [Pobrano

20.04.2017]. 
http://www.spiegel.de/netzwelt/web/erpressung-durch-cyberattacken-angriffszielindustrieanlage-a-1048034.html. [Pobrano 12.04.2017].

http://www.spiegel.de/netzwelt/gadgets/dhl-sicherheitsluecke-macht-packstationenangreifbar-a-1099054.html. [Pobrano26.04.2017].

http://www.europaeischer-referenzrahmen.de/sprachniveau.php. [Pobrano

22.04.2017].

http://isip.sejm.gov.pl/DetailsServlet?id=WDU19971330883. [Pobrano 22.04.2017]. https://www.gesetze-im-internet.de/bundesrecht/bdsg_1990/gesamt.pdf. [Pobrano

12.04.2017].

http://www.giodo.gov.pl/568/id_art/603/j/pl/. [Pobrano 20.04.2017].

http://eur-

lex.europa.eu/LexUriServ/LexUriServ.do?uri=CELEX:31995L0046:DE:HTML. [Pobrano 22.04.2017].

https://en.wikipedia.org/wiki/ISO/TC_37. [Pobrano 22.04.2017]. 